\title{
Access and Use of Resources by Women Agro-Processors in Central Agricultural Zone of Nasarawa State, Nigeria
}

\section{Salau, E. S. ${ }^{1}$; Bello, D. ${ }^{2}$ and Alanji, J. E ${ }^{3}$.}

1. Department of Agricultural Economics and Extension, Faculty of Agriculture Shabu-Lafia Campus,

Nasarawa State University, Keffi.

2. Department of Agricultural Extension and Management,

Nasarawa State College of Agriculture, Lafia.

3. Nasarawa Agricultural Development Programme (NADP)

Central zonal office Akwanga, Nasarawa State.

Corresponding Author's email: emmasalau@yahoo.com

\begin{abstract}
This study was carried out in the central agricultural zone of Nasarawa state to examine the level of access and use of productive resources by women agro-processors in the zone. A sample of 100 women agroprocessors from 3 LGAs that make up the zone was selected using proportionate random sampling technique. Data collection was done with the aid of an interview schedule during the 2012 cropping season. Data analysis involved the use of frequency, percentage, mean scores and ranking. The results show that the mean age of the respondents was 38 years. Majority (76\%) were married and most (42\%) of them were without any formal education. The mean year of experience in agroprocessing was 7 years. Most (74\%) of the respondents never obtained any loan in the past 3 years. The mean monthly income of the respondents was N18, 540. Most (40\%) of the processors got their raw materials directly from farmers' fields while majority (76\%) of them sold their outputs to consumers in the open markets. Most (56\%) of them used manual method of processing, most (54\%) of them never attended any training workshop on agro-processing. Most (42\%) of them received an average of 7 extension visits per year. Respondents had high level $(M>3)$ of access to raw materials, extension service, water supply, storage facilities and market for products. However, they faced the problems of inadequate capital, access to land, credit facility and price fluctuation. It was therefore recommended that reforms in the Land Use Act and agricultural credit scheme under the transformation agenda should be hastened up to enhance easy access to these resources by women. Cooperative societies should also be strengthened to fill the gap.
\end{abstract}

\section{Introduction}

Agriculture is the mainstay of most developing countries' livelihood especially in Nigeria. However, agriculture on its own is no longer able to provide a reliable livelihood for the growing populations in these countries (Mhazo et al, 2003). Small-scale farming in Nigeria rarely provides sufficient means of survival in many rural areas. It is therefore imperative to explore alternative income generating opportunities to support poor families who cannot fend for themselves from land-based activities alone. Alternative or additional income generating opportunities are needed to support the millions of poor families who can no longer support their livelihoods from the land alone.

Small-scale food processing activities represent a potential source of livelihood for many of such poor people in sub-Saharan Africa (Simalenga, 1996). 
The vision of the agricultural transformation initiative of the present government in Nigeria is to achieve a hunger free Nigeria through an agricultural sector that will drive income growth, accelerate achievement of food and nutritional security, generate employment and transform the country into a leading player in global food markets to grow wealth for millions of farmers. The agricultural transformation agenda is designed to make the agricultural sector a business project as against development project to promote private investment in agriculture, to execute integrated projects via value chain processes, generate employment, and transform Nigeria into a net exporter of agricultural commodities. It has high potentials for employment generation, food security, poverty reduction and industrialization. According to Babatunde (2012), the transformation action plan is focused on key aspects of value chains including the provision and availability of improved inputs (seeds, agrochemicals and fertilizer), increased productivity and production, as well as the establishment of staple crop processing zones. It is expected to address reduction in post-harvest losses, improving linkages with industries as well as access to financial services and markets. Mhazo et al. (2012) enumerated the overall potential of agro-processing to include the following: It can increase the value of crops of poor farmers and thus yielding higher returns; expand marketing opportunities; improve livelihoods of people; extend shelf-life of commodities; improve palatability of commodities; increase diversity of products; enhance food security by reducing food losses, increasing availability and improving access to food; overcome seasonality and perishability constraints; and empower women who are often more involved in agro-processing than men.

However, it is observed that although rural women are actively involved in agroprocessing and marketing in Nasarawa state, social and economic constraints have placed barriers around their access to production resources such as land, labour, capital, infrastructural facilities as well as extension services. Women's productivity in agriculture is highly dependent on their ability to access and use productive resources such as land, credit, improved seeds, fertilizer and other technologies. Lack of empirical data on the specific constraints and needs of women farmers and processors is responsible for the generalised recommendations that are often made by researchers leading to design of technologies that are not gender specific and inappropriate. The agricultural transformation agenda (ATA) targets rural communities particularly women, youth and farmers' associations, as well as improving rural institutions and infrastructure. In order to achieve its goals frantic efforts must be made by the government to liberalise access to production and processing resources by small scale farmers, especially women.

The purpose of this study was to assess the level of access and use of production resources by women agro-processors in Central Agricultural zone of Nasarawa state. The specific objectives were to: (i) identify the sources of information on agro-processing mostly used by the respondents; (ii) determine the level of access and use of production resources by the respondents; (iii) ascertain their training needs, and; (iv) identify the constraints facing women agro-processors in the area.

\section{Methodology}

The study was conducted in Central Agricultural Zone of Nasarawa State, which consists of four local government areas, namely Akwanga, Wamba, Kokona and NasarawaEggon with the zonal office at Akwanga. Three (3) out of the four LGAs in the zone were purposively selected. These were Akwanga, Nasarawa-Eggon and Wamba LGAs. A list of women agro-processors in each of the selected LGAs was obtained from the Fadama III office in the LGA. Fifty percent $(50 \%)$ of the number of women groups in each of the 3 LGAs was randomly selected. This gave a total of 10 women agro-processing groups. Also, 10 members were randomly selected from each group to give a total of 100 respondents. Data collection was done with the aid of an interview schedule during the 2012 cropping season. 
Data analysis was done using the Statistical Package for Social Sciences (SPSS) 15 version. Data were presented using frequency, percentage and mean scores.

\section{Results and discussion}

\section{Respondents' socioeconomic characteristics}

Entries in Table 1 show that majority (66\%) of the respondents were aged between 21 and 40 years. The mean age of the respondents was 38 years. Most $(76 \%)$ of the women agro-processors were married. A greater proportion (42\%) of the respondents did not acquire any formal education. It is generally believed that education creates a favourable mental attitude for the acceptance of new ideas and practices. Formal education enables a farmer to seek for and utilize useful information from both print and electronic media. Education accelerates the rate of adoption of technologies (Ozor and Madukwe , 2005 and Agbamu, 2006). Most (46\%) of the women processors had between $1-5$ years experience in agro processing, while the mean years of experience was 7 years. This implies that the respondents were relatively new in the business and may lack relevant skills in management of agro processing enterprise. Experience is important for effective day-to-day running of farm enterprise and could influence positively the adoption of innovations (Adebiyi, 2008). Majority (74\%) of the respondents did not use credit facility while $26 \%$ collected loans with an average of $\mathbb{A 1 4}, 220$. 00 per individual. This is probably due to the barriers to formal credit sources and the high interest rates of the informal credit sources. On their monthly income, majority (84\%) of the respondents received between $\$ 1,000-20,000$ per month with a mean of $\$ 18,540.00$ per month, which is equivalent to the present national minimum wage in Nigeria. This implies that agro processing is really a worthwhile enterprise for both rural and urban dwellers. 
Table1: Socioeconomic characteristics of respondents $(\mathrm{N}=100)$.

\begin{tabular}{|c|c|c|}
\hline Variable & $\begin{array}{l}\text { Percentage } \\
\text { (\%) } n=100\end{array}$ & Mean \\
\hline Age in years. & & 38 Years \\
\hline $21-40$ & 66.0 & \\
\hline $41-60$ & 30.0 & \\
\hline Above 60 & 4.0 & \\
\hline Marital status & & \\
\hline Single & 6.0 & \\
\hline Married & 76.0 & \\
\hline Widowed & 18.0 & \\
\hline Level of education & & \\
\hline Non formal education & 42.0 & \\
\hline Primary school & 28.0 & \\
\hline Secondary school & 20.0 & \\
\hline Tertiary education & 10.0 & \\
\hline Years of experience in agro-processing & & 7 Years \\
\hline $1-5$ & 46.0 & \\
\hline $6-10$ & 34.0 & \\
\hline $11-15$ & 18.0 & \\
\hline $16-20$ & 2.0 & \\
\hline Amount of loan received $(\mathrm{N})$ & & N14, 220. 00 \\
\hline Never used credit & 74.0 & \\
\hline $1000-50000$ & 14.0 & \\
\hline $51000-100000$ & 10.0 & \\
\hline $101000-150000$ & 2.0 & \\
\hline Monthly income level (N ) & & N18, 540. 00 \\
\hline $1,000-20,000$ & 84.0 & \\
\hline $21,000-40,000$ & 8.0 & \\
\hline $41,000-60,000$ & 4.0 & \\
\hline $61,000-80,000$ & 2.0 & \\
\hline above 80,000 & 2.0 & \\
\hline
\end{tabular}

\section{Sources of information used by respondents}

Table 2 shows that majority (54\%) of the respondents obtained relevant information from their processing associations, followed by $40 \%$ who relied on government extension agents, $31 \%$ used cooperative society while $28 \%$ used friends and neighbours as their information sources. It was observed that the respondents had very little or no patronage of modern mass extension methods such as radio (13\%), television (4\%), print media $(2 \%)$ and the Internet $(0 \%)$. This implies that the respondents relied on the traditional sources of information that are usually ineffective and inadequate. This is probably due to the high cost of the modern electronic sources such radio, television and Internet. This finding is similar to that of Umeta et al (2011) who reported that women farmers in the Mid Rift valley of Ethiopia did not patronise radio, television and printed materials for agricultural information. 
Table 2: Distribution of respondents based on sources of information used $(n=100)$.

\begin{tabular}{ll}
\hline Information source & Percentage $\mathbf{( n = 1 0 0 )}$ \\
\hline Extension Agents & 40.00 \\
Cooperative Society & 31.00 \\
Processing Association & 54.00 \\
Neighbours/Friends & 28.00 \\
Radio & 13.00 \\
Television & 4.00 \\
Print media & 2.00 \\
Internet & 0.00 \\
\hline
\end{tabular}

\section{Access to production resources by respondents}

Table 3 shows that the women agro-processors had easy access $(M>3)$ to six out of $13(46.2 \%)$ production resources presented. These were raw materials $(M=4.3)$; extension services $(M=3.86)$; water supply $(M=3.72)$; labour $(M=3.62)$; storage facilities $(M=3.44)$ and marketing facilities $(M=3.34)$. These resources are considered very critical for the success of any agro-processing enterprise. Having easy access to them will therefore enhance production at a reduced cost. The result however shows that the respondents had difficulty accessing resources such as credit facility, training programmes, land for expansion, machineries, information on modern processing method, transportation and electricity supply. Ogunlela and Mukhtar (2009) observed that lack of access to land remains a major constraint for women farmers in Africa and land reform programmes have led almost exclusively to the transfer of land rights to male heads of households. Even in countries where ownership and inheritance laws have been reformed in favour of women, in practice women do not necessarily have more rights to land, as local customs and lack of information act as barriers.

Table 3: Distribution of respondents based on level of access to production resources

\begin{tabular}{lll}
\hline Variable & Mean score & Ranking \\
\hline Extension services & $3.86^{*}$ & $2^{\text {nd }}$ \\
Credit facility & 2.2 & $13^{\text {th }}$ \\
Training programs & 2.9 & $7^{\text {th }}$ \\
Land for business site & 2.54 & $9^{\text {th }}$ \\
Machinery/equipment for processing & 2.54 & $9^{\text {th }}$ \\
Raw materials & $4.3^{*}$ & $1^{\text {st }}$ \\
Labour supply & $3.62^{*}$ & $4^{\text {th }}$ \\
Good market for products & $3.34^{*}$ & $6^{\text {th }}$ \\
Storage facilities & $3.44^{*}$ & $5^{\text {th }}$ \\
Information on processing & 2.4 & $11^{\text {th }}$ \\
Transport facilities & 2.9 & $7^{\text {th }}$ \\
Electricity & 2.34 & $12^{\text {th }}$ \\
Water supply & $3.72^{*}$ & $3^{\text {rd }}$ \\
\hline
\end{tabular}

${ }^{\star}=$ Highly accessible

\section{Sources of production resources used by respondents}

Table 4 shows the distribution of respondents according to their sources of production resources. A greater proportion (40\%) of the respondents obtained their raw materials directly from other farmers, $32 \%$ of them got them from their personal farms while $28 \%$ bought their raw materials from local markets. This implies that the women processors had dependable sources of raw materials either from their fellow farmers or their personal farms. 
Availability of a regular source of raw materials is a key ingredient in agro-processing enterprise.

Table 4 also shows that majority $(76 \%)$ of the respondents sold their output in the local markets, $22 \%$ sold to middlemen/wholesalers while $2 \%$ of the processors sold to companies/institutions. This implies that the respondents had ready markets for their products. This will enhance quick turn over and maximise profit. Results in Table 4 further show that majority (56\%) of the respondents used manual methods of processing while $44 \%$ used mechanised. This signifies that most agro-processing activities of women in the study area were manually done. This might result to small scale production with low quality of output.

Data in Table 4 also show that majority (72\%) of the respondent used hired equipment for their processing with only $28 \%$ having their personal equipment. This might add to cost of production and thereby reduce profit. Lack of personal equipment may also delay their operations since they would have to wait for some other persons to hire. Most (37\%) of the respondents sourced their loans from cooperative societies, $36 \%$ got their loans from friends/relations, $24 \%$ used the Bank of Agriculture while only $3 \%$ used commercial banks. This shows that most of the respondents utilised informal sources of credit rather than the formal sources. This might be as a result of the bureaucratic processes involved in accessing the formal credit sources which most rural farmers cannot cope with. Even though the informal credit sources might charge higher interest rate, they are easier to access. 
Table 4: Distribution of respondents according to sources of production resources

\begin{tabular}{ll}
\multicolumn{1}{c}{ used } & $\begin{array}{l}\text { Percentage } \\
(\mathbf{n}=100)\end{array}$ \\
\hline Variable & \\
\hline Sources of raw materials used & 32.0 \\
From personal farm & 40.0 \\
Direct from other farmers & 28.0 \\
From open market & \\
Source of market for output & 76.0 \\
Consumers in open market & 2.0 \\
Companies/institutions & 22.0 \\
Middlemen/ wholesalers & \\
Method of processing used & 56.0 \\
Manual method & 44.0 \\
Mechanized method & \\
Source of processing machine/equipment & 28.0 \\
Personal property & 72.0 \\
Hired/rented & \\
Sources of credit used & 36.0 \\
Relation/friends & 37.0 \\
Cooperative/thrift society & 3.0 \\
Commercial bank & 24.0 \\
Agricultural bank &
\end{tabular}

\section{Socioeconomic benefits of agro-processing to the respondents}

Table 5 shows that majority $(68 \%)$ of the respondents used agro-processing as a source of gainful employment, followed by $52 \%$ who used the proceeds to train their children in school, $42 \%$ used proceeds of the business to feed their families while $32 \%$ used it to build new houses. This implies that agro-processing is really a source of livelihood in the study area which can serve as a source of gainful employment to women and youth thereby reducing poverty. This finding is in agreement with the submission of Ekong (2003) that agro-processing can play a deliberate role in pro-poor growth strategies in the rural economy because earnings from it account for $30-45 \%$ of rural household income.

Table 5: Benefits derived from agro-processing by respondents

\begin{tabular}{lll}
\hline Variable & Frequency & Percentage (\%)(n=100) \\
\hline Major source of employment & 68 & 68.0 \\
Supplement family income & 14 & 14.0 \\
Training children in school & 52 & 52.0 \\
Feeding the family & 42 & 42.0 \\
Building of new house & 32 & 32.0 \\
Capital for other investments & 21 & 21.0 \\
\hline
\end{tabular}

\section{Perceived training needs of the respondents}

Table 5 shows the distribution of the respondents according to their perceived training needs. Majority $(60 \%)$ of them desired training on techniques of agro-processing followed by $58 \%$ who needed adult education while $22 \%$ expressed interest in business management training. This shows that there were training gaps to be filled. The women processors needed training in these three areas to build their capacities. 
Table 6: Training needs of respondents

\begin{tabular}{lc}
\hline Variable & Percentage $(\%)(\mathbf{n}=\mathbf{1 0 0})$ \\
\hline Adult literacy education & 58.0 \\
Business management & 22.0 \\
Technical skills in agro-processing & 60.0 \\
\hline
\end{tabular}

\section{Constraints to agro-processing in the area}

Table 7 shows the distribution of respondents according to constraints to agroprocessing. Majority $(72 \%)$ of the respondents were constrained by inadequate capital, followed by $66 \%$ who had difficulty accessing loans from banks, $52 \%$ had constraint of land for expansion of business, $44 \%$ faced the problem of unstable market prices and $34 \%$ of the respondents complained of high transportation cost among others. This clearly shows that the respondents were facing numerous problems in agro-processing businesses. This finding agrees with that of Mhazo, et al. (2012) who reported that agro-processors in Zimbabwe faced numerous constraints including poor equipment; shortages and high cost of equipment and spares; limited access to information from extension services; limited access to appropriate packaging material for processed products; lack of marketing skills; inadequate support services from training institutions, private sector consultants, small enterprise advisors, research institutions and engineering workshops; erratic power supply and high cost of processing equipment among others.

Table 7: Distribution of respondents according to constraints to agro-processing

\begin{tabular}{ll}
\hline Variable & Percentage(\%) (n=100) \\
\hline Inadequate capital & 72.00 \\
Inadequate land space for expansion & 52.00 \\
Difficulty in getting loan from banks & 66.00 \\
High interest rates on loan & 26.00 \\
Shortage of labour & 10.00 \\
Seasonal supply of raw materials & 18.00 \\
Poor power supply & 30.00 \\
High cost of transportation & 34.00 \\
Lack of personal machineries/equipment & 22.00 \\
Poor storage facilities & 8.00 \\
Poor marketing structures & 30.00 \\
High cost of raw materials & 26.00 \\
Poor extension services & 14.00 \\
Illiteracy & 22.00 \\
Market price fluctuation & 44.00 \\
\hline
\end{tabular}

Multiple responses. 


\section{Conclusion and Recommendation}

The study revealed that majority (66\%) of the agro-processors were aged between 21 and 40 years with a mean age of 38 years, most $(76 \%)$ of them were married and a greater proportion (42\%) of them had formal education. It also revealed that the mean year of processing experience was 7 years. Majority (74\%) of the respondents did not use credit facility while their mean monthly income $\$ 18,540$. 00 per month. Their major sources of processing information were the processing association (54\%) and government extension agents (40\%). The women agro-processors had easy access $(\mathrm{M}>3)$ to production resources such as raw materials $(M=4.3)$; extension services $(M=3.86)$; water supply $(M=3.72)$; labour $(M=3.62)$; storage facilities $(M=3.44)$ and marketing facilities $(M=3.34)$. Based on the findings it was concluded that agro-processing was really beneficial to the women however they were confronted with several constraints including inadequate capital, poor access to land, unstable market prices and high transportation cost among others. They also desired training on techniques of agro-processing, adult education business management. Based on the findings of the study and in line with the operations of the agricultural transformation agenda which is based on prioritization of commodity value chains along comparative advantage in the six geo political zones of the country and reform in the input supply sector, it was recommended that reforms in the Land use Act and agricultural credit under the transformation agenda should be hastened up to enhance easy access to these resources by women. Cooperative societies should also be strengthened to provide credit to agroprocessors at affordable rate. Extension organisations should incorporate agro-processing in their messages and training programmes for rural women to build their capacity.

\section{References}

Adebeyi, S. (2008). Factors affecting adoption of Cocoa rehabilitation techniques in Oyo State of Nigeria. Unpublished Masters Thesis; Department of Agricultural Economics and Extension, Federal University of Technology, Akure. Pp1-86.

Agbamu, J. U. (2006). Essentials of Agricultural Communication in Nigeria. Malthouse Press Ltd. Lagos, Nigeria. Pp 47-73.

Babatunde, B. (2012). Agricultural transformation agenda: Need for collaboration. Farmer's Chronicle Magazine, September 4th, 2012.

Ekong, E . E. (2003). Poverty and Rural Development in Nigeria: An Introduction to Rural Sociology. Dove Educational Publishers, Uyo. Nigeria, pp340-371.

Mhazo N.; Hanyani-Mlambo B.T.; Proctor S.; Mupanda K. and Nazare R. (2003). Constraints to Small-Scale Production and Marketing of Processed Food Products in Zimbabwe: The Case of Fruits and Vegetables. Paper presented at the Food Africa International Working Meeting, 5-9 May 2003, Palais des Congrès, Yaounde, Cameroon.

Mhazo, N.; Mvumi, B.M.; Elijah Nyakudya, E. and Nazare, R.M. (2012). The status of the agro-processing industry in Zimbabwe with particular reference to small- and mediumscale enterprises. African Journal of Agricultural Research Vol. 7(11), pp. 1607-1622, 19 March, 2012 .Available online at http://www.academicjournals.org/AJAR.

Ogunlela, Y.I. and Mukhtar, A. A. (2009). Gender issues in agriculture and rural development in Nigeria: The role of women. Humanity and Social Sciences Journal 4 (1): 19-30, 2009. ISSN 1818-4960. 
Ozor, N. and Madukwe, M.C. (2005). Obstacles to the adoption of improved rabbit technologies by small scale farmers in Nsukka LGA. Journal of Agriculture, Food, Environment and Extension, Agro-science vol. 4(1). January 2005. Pp $70-73$.

Simalenga, T.E. (1996). Small-scale decentralised agro-processing. Paper presented at Small-Scale Decentralised Agro-industry Seminar in Harare, Zimbabwe.

Umeta, G.; Lemecha, F. and Mume, T. (2011). Survey on women access to agricultural extension services at selected districts of Mid Rift Valley of Ethiopia. Journal of Agricultural Extension and Rural Development Vol. 3(3), pp. 51-63, March 2011. Available online at http:// academicjournals.org/JAERD. Accessed on 2/10/12 